Dr Jugoslav Kodžopeljić, general-potpukovnik, dipl. inž. EI Holding korporacija, Niš

Dr Petar Stanojević, major, dipl. inž. Vojnotehnicka akademija VJ, Beograd

\section{AKTIVNOSTI IZADACI LOGISTIČKE PODRŠKE U ŽIVOTNOM VEKU TEHNIČKIH SISTEMA}

UDC: $355.41: 62$

Rezime:

Da bi tehnicki sistemi obavljali svoje funkcije u skladu sa definisanim potrebama, treba da budu optimizirani $i$ sa stanovišta logisticke podrške. $U$ radu su navedeni zadaci logisticke podrske $i$ aktivnosti kojima se ti zadaci realizuju, uzimajuci u obzir ukupan vek trajanja tehničkih sistema. Pošto se tehnicki sistemi razvijaju i eksploatišu kroz faze: studija, prethodna analiza, program realizacije, projektovanje (idejni projekat ili pretprojekat), materijalizacija (funkcionalni model, probni komad, prototip, prototipska partija), osvajanje proizvodnje, serijska proizvodnja, eksploatacija i održavanje, predmetne aktivnosti su prikazane za svaku od navedenih faza ili njihovih delova.

KljuČne reči: logisticka podrška, tehnicki sistemi, sistemski pristup, aktivnosti logističke podr'ske, faze životnog veka tehnickih sistema.

\title{
ACTIVITIES AND TASKS OF LOGISTIC SUPPORT IN THE LIFE CYCLE OF TECHNICAL SYSTEMS
}

\section{Summary:}

In order to function according to defined requirements, technical systems should be also optimized from the aspect of logistic support. The tasks of logistic support and the activities for their realization have been given taking into account the overall life cycle of technical systems. Since technical systems are being developed and used through the following phases: study, preliminary analysis, realization program, design (project or preliminary project), materialization (functional model, test specimen, prototype, prototype series), production conquering, mass production, service and maintenance, characteristic activities have been presented for each of the given phases or their parts.

Key words: logistic support, technical systems, system approach, logistic support activities, life cycle phases of technical systems.

\section{Uvod}

Tehniðki sistemi i tehnickka sredstva u svom veku prolaze kroz sledeće faze: planiranje, programiranje, projektovanje, razvoj, proizvodnja, ugradnja, eksploatacija i održavanje. Kroz sve ove faze teži se realizaciji takvog tehnickog si- stema koji ce obezbeđivati najveći stepen efektivnosti uz minimalne troß̌kove, odnosno sistemu koji ce maksimalno zadovoljiti kriterijum ekonomske efektivnosti. $\mathrm{Za}$ rešavanje ovog problema, u poslednjih pedesetak godina, formirao se celoviti pristup pod nazivom integralna logistička podrška ili integralno tehničko 
obezbeđenje. Taj pristup se dokazao kao jedini realno primenljivi i isplativi put za smanjivanje ukupnih troškova životnog veka tehničkih sistema, i povećavanje njihovog upotrebnog kvaliteta. Suština pristupa je u sagledavanju svih pojava vezanih za tehnički sistem u toku celokupnog, (programiranog), njegovog životnog veka. Potreba za sagledavanjem svih pojava u toku celokupnog životnog veka uslovljena je dokazanim činjenicama da se najveći deo troškova generiše u fazama eksploatacije i održavanja (a ne u prethodnim fazama), ali i da generatore visokih troškova i nedostataka u kvalitetu treba tražiti prvenstveno u fazama životnog veka koje prethode eksploataciji i održavanju. Indikativna je i činjenica da se troškovi za eliminisanje konstrukciono-tehnoloskih nedostataka u razradi projekta, pri izradi serije i u eksploataciji nalaze u odnosu $1: 10: 100$. Ove činjenice govore o međusobnom uticaju faza životnog veka i potrebi da se problem rešava kao celina, odnosno da se pri donošenju odluka uvek imaju u vidu posledice koje ce odluke donete u jednoj fazi životnog veka imati na događaje u ostalim fazama.
Da bi se obezbedilo smanjenje troškova i povećanje upotrebnog kvaliteta, danas je već potpuno jasno, logističkoj podršci mora se pokloniti odgovarajuća pažnja, jer je ona ključna za efektivnost tehničkih sistema u naredne dve faze životnog veka. To znači da se sadržaji logističke podrške nužno moraju, na odgovarajući način, razmatrati u celom životnom veku tehničkih sistema i sredstava. Zbog toga, tim značajnim aktivnostima mora se po fazama životnog veka tehničkog sistema pristupiti sistemski i sistematizovano, odnosno, o njima se mora voditi računa već od početne faze tj. od planiranja. Naravno, kako projekat napreduje tako se rešenja konkretizuju ili logistička podrška realizuje. Iskustva iz svetske prakse (na primeru razvoja jednog radarskog sistema u Švedskoj) govore da se najveći deo odluka o tehničkom sistemu donese na samom poðetku njegovog razvoja (slika 1 ).

Razvoj posmatranog tehničkog sistema trajao je oko tri godine. Ukupno je doneto oko 2700 razvojnih-projektantskih odluka-rešenja. Od toga 1500 (ili

2700 odluka

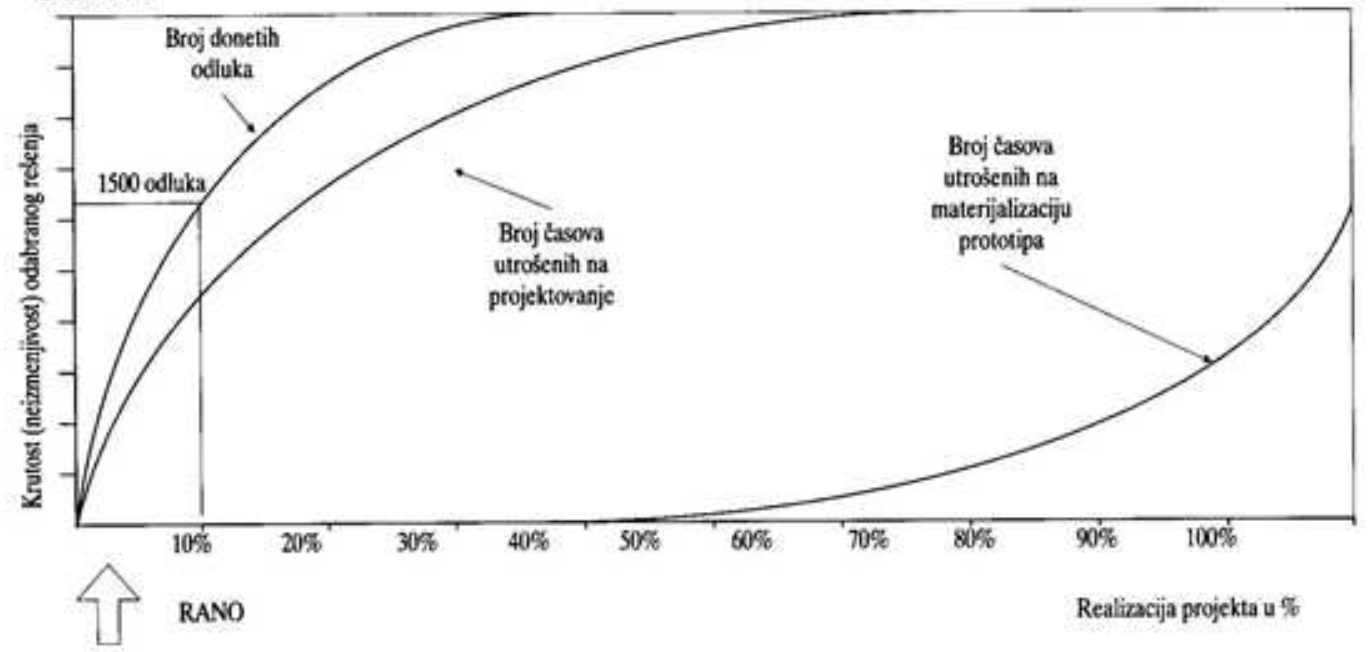

SI. 1 - Dijagramski prikaz razvoja složenog tehničkog sistema 


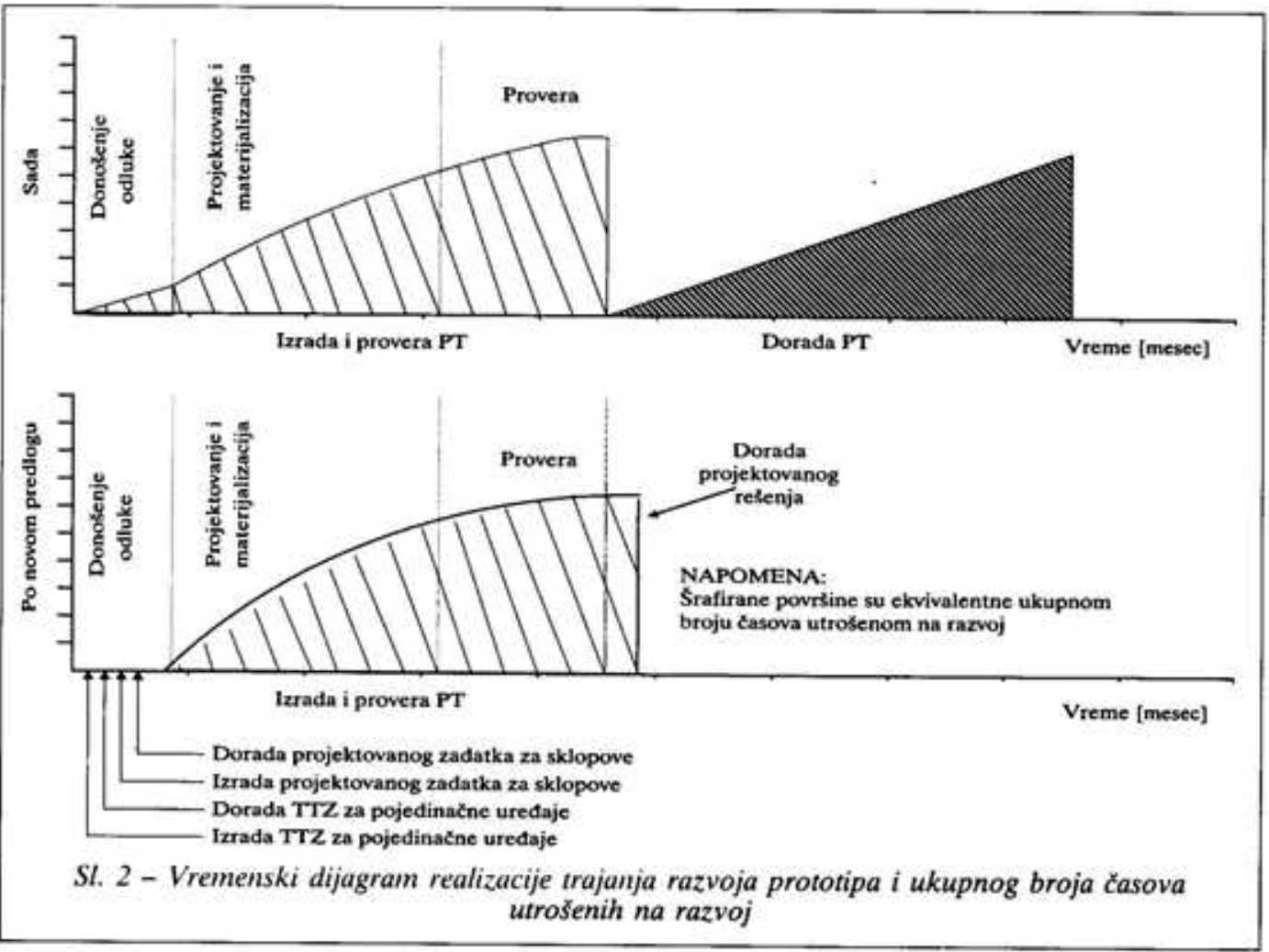

oko $60 \%$ ) doneto je za samo $10 \%$ od ukupnog trajanja razvoja. Samo donošenje odluka završeno je za oko $40 \%$ vremena razvoja, dok je projektovanje (realizacija odluka) trajalo oko $70 \%$ vremena razvoja. Sa materijalizacijom rešenja otpočelo se praktično tek po donošenju svih odluka. Ovi podaci govore o značaju pravovremene ugradnje logisticke podrške, odnosno o nužnosti njenog razmatranja od najranijih faza životnog veka tehničkog sistema, ali i o tome da ne treba žuriti sa materijalizacijom tehničkog sistema dokle god daleko najveći deo problema nije rešen "na papiru“, odnosno dok sve relevantne i sveobuhvatne odluke nisu donete, jer je to sigurno put koji zahteva manja ulaganja. Ukoliko se to ne učini može doci do situacije prikazane na slici 2.
$\mathrm{Na}$ gornjem dijagramu prikazan je slučaj kada se sa materijalizacijom (u ovom slučaju prototipa) započne od najranijih faza projektovanja (kao što je, nažalost, još uvek cest slučaj u praksi). To ce sigurno, posle faze provere, dovesti do potrebe za većim doradama i produžavanjem vremena razvoja. Ako se količina rada na projektovanju shvati kao šrafirana površina, sa dijagrama se vidi da se ona može znatno povećati, u prvom slucaju, zbog potrebnih dorada prototipa. Takođe, produžiće se i vreme razvoja. U drugom slučaju (donji dijagram), ukoliko se sve relevantne odluke o tehničkom sistemu donesu sveobuhvatno i pre započinjanja materijalizacije, može se očekivati da ce dodatna količina rada na projektovanju i vreme produžetka trajanja projektovanja biti kao što je slikovito 


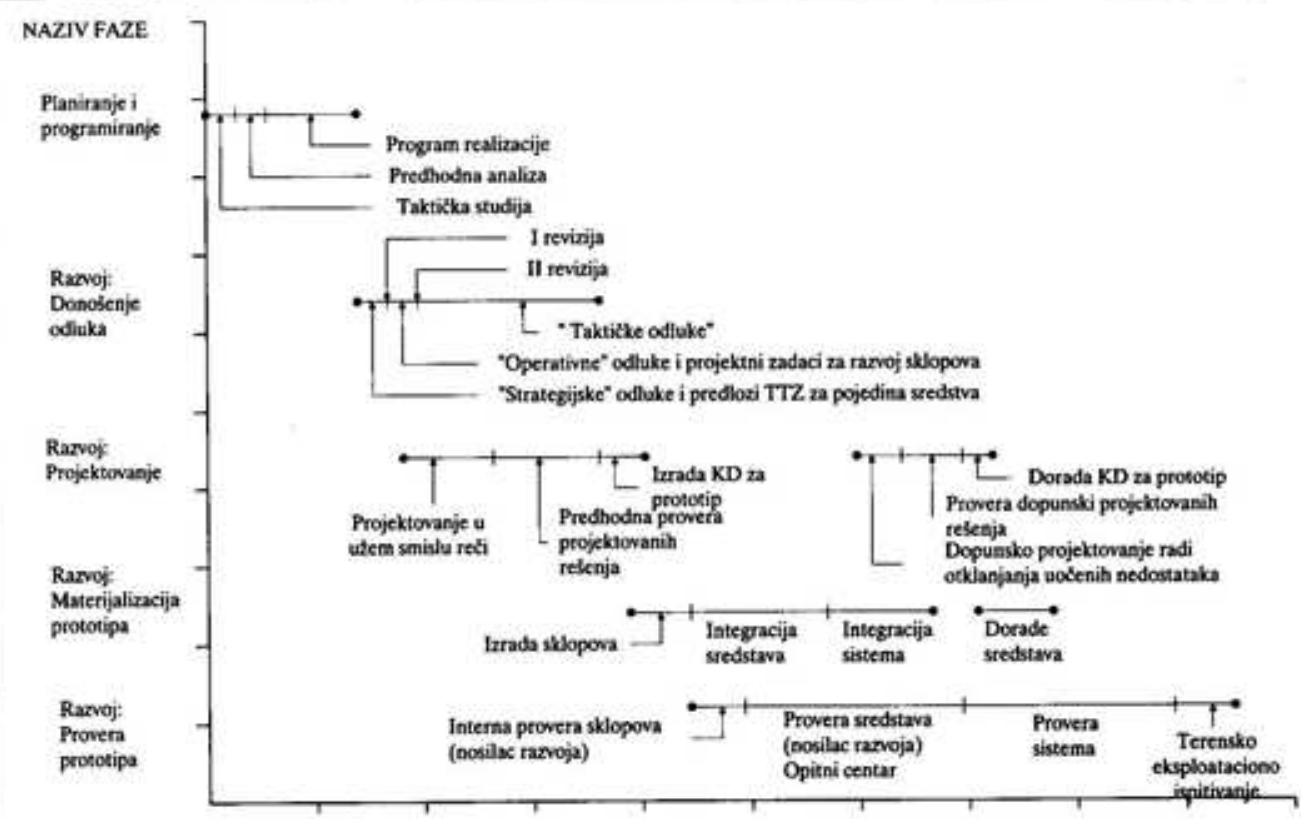

Sl. 3 - Gantogram vremenske uslovljenosti faza planiranja, programiranja i razvoja novog tehnickog sistema

prikazano sa desne strane isprekidane linije.

Uzimajući u obzir da se tehnički sistem praktično realizuje izradom određenih dokumenata (kojima se pojedine faze životnog veka verifikuju) i odgovarajućom materijalizacijom, odnosno eksploatacijom, mogu se prihvatiti sledeće aktivnosti i dokumenta, kao ključni: studija za tehnički sistem, prethodna analiza tehničkog sistema, program realizacije, ugovaranje projektovanja i razvoja (ili projektovanje i razvoj), izrada idejnog projekta ili pretprojekta, izrada detaljnog projekta, izrada funkcionalnog modela ili probnog komada, izrada prototipa ili prototipske partije, osvajanje proizvodnje i serijska proizvodnja, izrada nulte serije, serijska proizvodnja, eksploatacija i odrzavanje. Gantogram aktivnosti planiranja, programiranja i razvoja novog tehničkog sistema (slika 3) pokazuje svu složenost i vremensku uslovljenost među realizacijom i rezultatima ovih aktivnosti - faza (procesa).

U svim navedenim fazama (aktivnostima) moraju se realizovati zahtevi logističke podrške. To se postiže odgovarajućim aktivnostima i realizacijom odgovarajućih zadataka.

\section{Aktivnosti i zadaci logističke podrške}

Logistički pristup u oblasti tehnickih sistema i sredstava danas još uvek nije potpuno sistemski zaokružen. Kada je ovaj pristup u pitanju u literaturi se susreću različiti sadržaji aktivnosti i zadataka, kako u svetu, tako i u domaćoj praksi.

Svetska iskustva na ovom planu sistematizovana su, prvenstveno, kroz više standarda americke vojske $[1,2,3,4,5]$. Sadržaj ovih dokumenata prvenstveno je 
vezan za ugradnju i poboljšanje pouzdanosti i pogodnosti za održavanje pri razvoju tehnickih sistema. Njima je delimično i na specifičan način obuhvaćena celina odnosa i međuzavisnosti koje, pri ugradnji logističke podrške, mogu međusobno imati projektant, proizvođač i kupac - naručilac tehničkog sistema.

Domaća istraživanja pokazuju da je zadovoljavajuci način obuhvata tih zadataka kako je to navedeno u literaturi [6]. Naime, kada se govori o sveobuhvatnosti aktivnosti i zadataka logističke podrške u životnom veku tehničkih sistema i sredstava, moguće je pod tim podrazumevati realizaciju različitih zadataka." Može se zaključiti da su zadaci mnogobrojni, neki su bitni u poðetnoj fazi realizacije, a drugi tek u eksploataciji i održavanju, vecina je interdisciplinarnog karaktera, svi utiču na efektivnost $i$ cenu tehnickog sistema, za realizaciju pojedinih zadataka je potrebno iskustvo, a neki traže i modeliranje, itd. Sve to ukazuje na nužnost njihovog rešavanja sistemskim putem i pravovremeno.

Iskustvo stečeno dugogodišnjim radom na razvoju tehničkih sistema, njihovoj proizvodnji, eksploataciji i održavanju, upućuje na to da je nužno slediti sledeci model - dat u vidu faznog algoritma:

- postaviti početne zahteve u kvantitativnom i kvalitativnom pogledu;

- alocirati zahteve po tehnickim sredstvima, agregatima, sklopovima, podsklopovima, modulima i delovima;

- prognozirati kvantitativne vrednosti po osnovnim agregatima, sklopovima, podsklopovima i modulima;

- „ugraditi“ zadate vrednosti po agregatima, sklopovima i podsklopovima;

- proračunati vrednosti logističke podrške za ceo životni vek;
- ispitati realizovane vrednosti logističke podrške;

- verifikovati ispitivanjem dobijene vrednosti logističke podrške ili ih verifikovati na završnim ispitivanjima;

- realizovati aktivnosti praćenja logističke podrške pri upotrebi $i$ održavanju;

- korigovati elemente logističke podrške koji su nastali kao rezultat pracenja u praksi;

- modifikovati tehnički sistem u pogledu prilagođavanja tehnickog sredstva novim logističkim mogućnostima.

$\mathrm{U}$ toku realizacije navedenih aktivnosti preporučuje se i primena sledećih standarda, propisa i preporuka:

- JUS A.A2.005/85 - Pouzdanost

(Osnovni termini i definicije),

- JUS IEC 300/92 - Upravljanje pouzdanošcu i pogodnošću za održavanje,

-1. - Predmet, naziv i sastav tehnickog sistema ili sredstava

2. - Kompatibilnost sa sredstvima ili sistemima sa kojima treba da radi

3. - Tehnicko-eksploatacione karakteristike

4. - Broj, stručnost i psiho-fizicke osobine posluge, vozača i rukovalaca

5. - KlimamehaniCki uslovi eksploatacije i održavanja

6. - Bezbednost pri rukovanju i odrzavanju

7. - Zakonski i drugi propisi

8. - Eksploatacione potrebe u toku veka trajanja

9. - Zastita u incidentnim situacijama

10. - Zastita od elektronskih i drugih dejstava

11. - Sprečavanje sopstvenih neželjenih zračenja

12. - Napajanje tehnickih sistema i sredstava električnom energijom

13. - Obezbedenje potrebne operativne gotovosti odnosno raspoloziwosti ili spremnosti

14. - Obezbeđenje standardizacije, tipizacije i unifikacije

15. - Obezbedenje pouzdanosti

16. - Obezbedenje pogodnosti za rukovanje i odrzavanje

17. - Obezbedenje uslova u pogledu logistike odrżavanja (preventivno i korektivno odrzavanje u celokupnom veku trajanja)

18. - Obezbeđenje zastite na radu pri radu sa tehniCkim sistemom ili sredstvom

19. - Obezbeđenje uslova za transport i eventualno skladistenje

20. - Obezbeđenje konstrukcione i tehnoloßke dokumentacije, dokumentacije kvaliteta i tehnicke dokumentacije za rukovanje i odrłavanje

21. - Obezbeđenje kadra za proizvodnju, rukovanje i održa. vanje

22. - Obezbeđenje sistema rezervnim delovima u veku trajanja

23. - Obezbeđenje opreme za odrzavanje $i$ ispitne opreme

24. - Obezbeđenje individualnog $\mathrm{i}$ grupnog kompleta alata. pribora i rezervaih delova 
- JUS IEC 605-3-1/92 - Ispitivanje pouzdanosti uređaja (Preporučeni uslovi ispitivanja za prenosne uređaje koji se koriste u zatvorenim prostorijama - nizak stepen simulacije),

- JUS IEC 605-3-2/92 - Ispitivanje pouzdanosti uređaja (Preporučeni uslovi ispitivanja uređaja za stacionarnu upotrebu koji se koriste u zatvorenim prostorijama),

- JUS IEC 605-4 (u pripremi) Ispitivanje pouzdanosti uređaja (Postupci za određivanje tačkastih ocena i granica poverenja na osnovu ispitivanja pouzdanosti uređaja),

- JUS IEC 605-5/92 - Ispitivanje pouzdanosti uredaja (Planovi provere ispunjenja zahteva za uspešnost - ili relativnu uspešnost),

- JUS IEC 605-6 (u pripremi) Ispitivanje pouzdanosti uređaja (Provera valjanosti pretpostavke o konstantnom intenzitetu otkaza),

- JUS IEC 605-7 (u pripremi) Ispitivanje pouzdanosti uređaja (Provera zahteva za intenzitet otkaza i srednje vreme između otkaza u slučaju važenja pretpostavke o konstantnom intenzitetu otkaza),

- JUS IEC 50 (191) (u pripremi) Pouzdanost, pogodnost za održavanje $i$ kvalitet usluge (Osnovni termini i definicije),

- SNO 0477/83 - Elementi koji se razmatraju prilikom ugovaranja sredstava i sistema naoružanja $i$ vojne opreme,

- SNO 0588/81 - Rešenje o usvajanju $i$ uvođenju sredstva NVO u naoružanje $i$ opremu OS SFRJ (Oblik i sadržaj),

- SNO 1096/85 - Takticko-tehnički zahtevi za razvoj tehničkih materijalnih sredstava,

- SNO 4077/89 - Elektromagnetska kompatibilnost,
- SNO 4265/84 - Pouzdanost (Provera zahteva za srednje vreme između otkaza u slučaju eksponencijalne raspodele),

- SNO 5619/86 - Trajnost (Provera ispunjenja zahteva za radni vek i procena veka proizvoda),

- SNO 5706/84 - Ispitivanje uticaja okoline na elektronske i elektromehaničke uređaje i pribor za potrebe KoV-a,

- SNO 8348 (u pripremi) - Određivanje troškova veka sredstava NVO,

- ISO 9000-SNO 9000/90 - Opšti zahtevi za sistem kvaliteta isporučioca naoružanja $i$ vojne opreme,

- 409 - Uputstvo za uključivanje odredbi u pogledu pouzdanosti $u$ zahteve za komponente (ili delove) elektronskih uredaja,

- 706 - Uputstvo za obezbedenje pogodnosti za održavanje (Deo 1: Uvod u pogodnost za održavanje; Deo 2: Odredbe u pogledu pogodnosti za održavanje u zahtevima i ugovorima; Deo 3: Program obezbeđenja pogodnosti za održavanje; Deo 4: Projektovanje pogodnosti za održavanje; Deo 5: Provera pogodnosti za održavanje; Deo 6: Prikupljanje, analiza i predstavljanje podataka koji se odnose na pogodnost za održavanje; Deo 7: Planiranje održavanja i podrške održavanju),

- 863 - Prikazivanje procena pouzdanosti, pogodnosti za održavanje $i$ raspoloživost,

- Dodatak IEC preporuci 300 Upravljanje pouzdanošcu $i$ pogodnošću za održavanje softvera,

- IEC (CO)-Smernice za propisanu reviziju projekta,

- MIL-HDBK-217E - Procena pouzdanosti elektronskih uređaja,

- MIL-STD-470 i MIL-STD-470A Pogodnost za održavanje sistema i uredaja (zahtevi, verifikacija, ocena) itd. 
Međutim, ostaje problem konkretizacije postupka ugradnje logističke podrške po fazama životnog veka, što podrazumeva izbor odgovarajucih (primerenih) aktivnosti, vreme ugradnje, dubinu zahvata, potrebne resurse, itd. Cilj ovog rada je da se preciziraju aktivnosti na ugradnji logističke podrške u toku životnog veka tehničkih sistema.

$\mathrm{U}$ vidu tabelarnog pregleda aktivnosti, za sve faze veka tehničkog sistema ili sredstva, dato je rešenje čijom se realizacijom postižu traženi efekti. Na taj način dovedene su u vezu faze životnog veka tehničkog sistema sa odgovarajućim aktivnostima ugradnje logističke podrške, njihovim sadržajem, vremenom ugradnje, dubinom zahvata, nosiocima i potrebnim resursima.

Sve nabrojane aktivnosti (u tabelama) u pogledu obaveznosti primene svrstane su u tri kategorije:

- A - obavezna primena;

- B - treba primeniti (odustajanje od aktivnosti označene sa B mora biti regulisano međusobnim ugovorom narucioca $\mathrm{i}$ izvođača ili njegovom dopunom);

- C - poželjno je da se primeni (odluku o odustajanju od aktivnosti označne sa $\mathrm{C}$ može doneti i sam izvođač, ali sa njom, ipak, mora blagovremeno upoznati naručioca).

Aktivnosti koje se realizuju u okviru izrade tehničke studije projekta tehnickog sistema, nosioci njihove realizacije i obaveznost primene, navedeni su u tabeli 1 .

Aktivnosti koje se realizuju u okviru izrade prethodne analize - (PA), nosioci njihove realizacije, saradnici i obaveznost primene, navedeni su u tabeli 2 .

Aktivnosti koje se realizuju $u$ toku ugovaranja izrade programa realizacije $(P R)$, nosioci njihove realizacije i obaveznost primene, navedeni su u tabeli 3 .
Aktivnosti koje se realizuju u okviru izrade programa realizacije, nosioci njihove realizacije, saradnici i obaveznost primene navedeni su u tabeli 4 .

Aktivnosti koje se realizuju $u$ toku ugovaranja projektovanja $i$ razvoja, nosioci njihove realizacije $i$ obaveznost primene, navedeni su u tabeli 5 .

Aktivnosti koje se realizuju $u$ toku izrade idejnog projekta ili pretprojekta, nosioci njihove realizacije, saradnici $i$ obaveznost primene, navedeni su u tabeli 6. Idejni projekat ili pretprojekat obavezno se radi za sisteme i podsisteme tehničkog sistema, a po mogućnosti i za složena tehnička sredstva.

\section{Aktivnosti koje se realizuju u toku izrade detaljnog projekta}

Detaljni projekt je početna etapa prototipskog razvoja. Ona obuhvata pronalaženje optimalnog, detaljnog rešenja, a zatim i razradu konstrukcione dokumentacije (u daljem tekstu: KD) na osnovu koje se (prema očekivanju) može fizički materijalizovati tehničko sredstvo ili sistem koji u potpunosti zadovoljava sve postavljene TEZ i ostale ugovorom propisane zahteve kupca.

Detaljni projekat se obavezno radi za svako pojedinačno tehničko sredstvo bez obzira na to da li se ono koristi samostalno ili u sastavu složenog sredstva, podsistema ili tehničkog sistema. Izuzetno od toga se, u slučaju veoma kompleksnih složenih tehničkih sredstava i sistema, može, pored detaljnih projekata pojedinačnih sredstava (koja ulaze u njegov sastav) raditi i detaljni projekat sistema, odnosno složenog tehničkog sredstva.

$\mathrm{U}$ toku izrade detaljnog projekta tehničkog sistema i sredstva, po pravilu, realizuju se aktivnosti navedene u tabe- 
li 7, u kojoj su prikazani i nosioci njihove realizacije, saradnici i obaveznost primene.

\section{Aktivnosti koje se realizuju u toku izrade funkcionalnog modela ili probnog komada}

U slučaju prototipskog razvoja tehničkih sistema ili složenih sredstava, etapi konačne materijalizacije prototipa (u daljem tekstu: PT) može prethoditi etapa materijalizacije funkcionalnog modela. Funkcionalni model je materijalizovana verzija razvijenog sredstva koja zadovoljava zahteve normalnog funkcionisanja, ali ne zadovoljava neke, u posmatranom trenutku, manje bitne zahteve (npr. zadovoljeni su svi zahtevi za normalne uslove upotrebe, ali ne i neki od zahteva za ekstremno nepovoljne uslove ili nacin upotrebe; ili, model je izrađen od delova, odnosno sklopova nabavljenih na tržištu ili proizvedenih pomoću mašina opšte namene, dok ce se u prototip ugraditi namenski projektovani i proizvedeni sastavni delovi (s/d) optimalno prilagođeni zadovoljenju nekog od postavljenih zahteva - npr. delovi ugrađeni u prototip biće: manji ili lakši, pouzdaniji, sposobniji da izdrže veće varijacije temperature, postojaniji u pogledu postepene promene fizičko-hemijskih karakteristika, brži u pogledu reagovanja, čvršci, itd.).

Probni komad nacelno predstavlja prvo približavanje rešenju tehničkog sredstva. Pored toga, može biti jedan od rezultata primenjenih istraživanja. Izrađuje se, po pravilu, u više varijanti radi ispitivanja kvaliteta ugrađenih materijala ili funkcije sklopova $i$ celine.

$\mathrm{U}$ toku izrade funkcionalnog modela ili probnog komada, kojoj je prethodila faza izrade detaljnog projekta, po pravilu se realizuju zadaci navedeni u tabeli 8 , u kojoj su prikazani i nisioci njihove realizacije, saradnici i obaveznost primene. Međutim, ako pre početka rada na funkcionalnom modelu nije postojao detaljan projekt, tada se i ovo projektovanje realizuje u toku izrade funkcionalnog modela ili probnog komada. U tom slučaju se iza zadatka 1 iz tabele 8 nastavlja sa realizacijom zadatka 2 do 23 iz tabele 7 , a zatim nastavlja sa zadacima od 2 do 11 iz tabele 8 .

\section{Aktivnosti koje se realizuju u toku izrade prototipa (PT) ili prototipske partije (PP)}

Materijalizacija PT ili PP zadnja je etapa prototipskog razvoja, i u njoj se fizički ostvaruju konstrukciona rešenja detaljnog projekta, i objektivno proverava da li ce ona zadovoljiti sve postavljene TEZ. Pored toga, proverava se kvalitet svih ugrađenih $\mathrm{s} / \mathrm{d}$ i materijala, razrađuju se, a po mogućnosti i upotpunjavaju elementi koji obezbeđuju namensku i autonomnu funkciju tehničkog sredstva ili sistema (izvori energije, individualni komplet rezervnih delova, alata i pribora, ambalaža za transport i Cuvanje), daju zahtevi za specijalnu remontnu opremu za nivo tehničkog održavanja i nastavna sredstva, kao i nacrti uputstava za rukovanje i tehničko održavanje.

U toku izrade PT ili PP, kojoj je prethodila izrada detaljnog projekta, realizuju se aktivnosti navedene u tabeli 9 . Međutim, ako se PT ne radi po razrađenom i usvojenom detaljnom projektu, onda izrada ovog projekta mora biti integrisana sa izradom PT. U tom slučaju, u okviru izrade PT realizuju se sve aktivnosti navedene u tabelama 7 i 9 . Na kraju, ako je pre početka izrade PT prvo izrađen 
i proveren funkcionalni model, ili probni komad, tada se u okviru izrade PT, odnosno PP, ne realizuju zadaci koji su u tabeli 9 označeni sa "*".

Aktivnosti koje se realizuju u toku ugovaranja osvajanja proizvodnje $i$ serijske proizvodnje, nosioci njihove realizacije, saradnici i obaveznost primene navedeni su u tabeli 10 .

Aktivnosti koje se realizuju u toku izrade " 0 " serije, nosioci njihove realizaci$j e$, saradnici $i$ obaveznost primene navedeni su u tabeli 11. $U$ toj tabeli nisu prikazani najvažniji zadaci izrade nulte serije (npr. izrada i nabavka proizvodnih alata, proizvodnja sredstava $i$ drugo) zato što nisu kritični sa stanovišta logističke podrške.

Aktivnosti koje se realizuju u toku serijske proizvodnje, nosioci njihove realizacije, saradnici i obaveznost primene navedeni su u tabeli 12 .

U tabeli 12 nisu navedeni najvažniji zadaci serijske proizvodnje (npr. proizvodnja samih tehničkih sredstava) zbog toga što oni nisu kritični sa stanovišta logisticke podrške.

Aktivnosti koje se realizuju radi obezbeđenja ugradnje tehničkog sredstva u složeno sredstvo ili sistem, odnosno ugradnje tehničkog sistema u objekat

Ako je, na osnovu ukazane potrebe, neophodno da se neko od tehničkih sredstava ugradi u određeno složeno sredstvo ili sistem ili ako je doneta odluka da se neki tehnicki sistem ili postrojenje ugradi u određeni specifični objekat, tada se, u okviru rešenja ugradnje, obično realizuju zadaci navedeni u tabeli 13 . U ovoj tabeli definisani su i nosioci realizacije, saradnici i obaveznost primene.
Aktivnosti koje se realizuju u toku eksploatacije $i$ održavanja

Obaveze nosioca razvoja i proizvođača tehničkih sistema i sredstava ne završavaju se sa prestankom razvoja ili proizvodnje ovih sredstava. One se produžuju i na period eksploatacije kada se, po pravilu, izvršavaju zadaci navedeni u tabeli 14. U ovoj tabeli definisani su i nosioci realizacije, saradnici i obaveznost primene.

\section{Zaključak}

$\mathrm{Za}$ realizaciju zadataka logističke podrške tehničkih sistema u toku njihovog životnog veka potrebna je odgovarajuća metodologija sistemskog pristupa. Metodologija opisana u ovom radu je opšteg karaktera, a za svaki projekat se posebno razmatra i konkretizuje. Ovaj pristup može se primeniti i pri nabavci tehničkih sistema i sredstava koja se kupuju kao gotovi proizvodi na tržištu, radi sagledavanja stepena realizacije logističke podrške. Naravno, u tom slučaju postupak je prilagođen takvoj situaciji.

Treba uočiti da kupcu i direktnom korisniku ovakva metodologija (postupak) pomaže da jasnije i preciznije odrede zahteve u pogledu logističke podrške, predvide aktivnosti kojima ce se obezbediti ugradnja ovih zahteva i mogućnost pravovremene kontrole realizacije aktivnosti i zadataka.

Proizvođačima ova metodologija omogućava da bolje shvate zahteve za ostvarenje i proveru propisanih karakteristika logističke podrške, sugeriše ili preporučuje put njihove ugradnje i olakšava određivanje realne cene, odnosno, ekonomske podrške projekta u celini. 
Aktivnosti koje se realizuju u okviru tehničke studije projekta

\begin{tabular}{|c|c|c|c|c|}
\hline $\begin{array}{c}\text { Redni } \\
\text { broj }\end{array}$ & Naziv aktivnosti & $\begin{array}{c}\text { Nosilac } \\
\text { realizacije }\end{array}$ & Sarađuje & $\begin{array}{c}\text { Obaveznost } \\
\text { primene }\end{array}$ \\
\hline 1 & 2 & 3 & 4 & 5 \\
\hline 1. & $\begin{array}{l}\text { Definisanje najbitnijih tehnicko-eksploatacio- } \\
\text { nih zahteva (u daljem tekstu: TEZ) i kriteri- } \\
\text { juma eksploatacije u veku trajanja tehničkog } \\
\text { sistema }\end{array}$ & $\begin{array}{l}\text { Razvojni } \\
\text { organ kupca }\end{array}$ & $\begin{array}{l}\text { Razvojni organ } \\
\text { proizvođača }\end{array}$ & $\mathrm{A}$ \\
\hline 2. & $\begin{array}{l}\text { Propisivanje posebnih zahteva u pogledu sme- } \\
\text { staja i odrźavanja }\end{array}$ & $*$ & $n$ & $\mathrm{~A}$ \\
\hline
\end{tabular}

Tabela 2

Aktivnosti koje se realizuju u okviru prethodne analize

\begin{tabular}{|c|c|c|c|c|}
\hline $\begin{array}{c}\text { Redni } \\
\text { broj }\end{array}$ & Naziv aktivnosti & $\begin{array}{l}\text { Nosilac } \\
\text { realizacije }\end{array}$ & Sarađuje & $\begin{array}{l}\text { Obaveznost } \\
\text { primene }\end{array}$ \\
\hline 1 & 2 & 3 & 4 & 5 \\
\hline 1. & $\begin{array}{l}\text { Definisanje opisa tehnickog sistema i organi- } \\
\text { zacijskih resenja u vezi s njegovom primenom }\end{array}$ & $\begin{array}{l}\text { Razvojni } \\
\text { organ kupca }\end{array}$ & - & A \\
\hline 2. & $\begin{array}{l}\text { Određivanje modela (koncepta) eksploatacije } \\
\text { i osnovnog održavanja }\end{array}$ & " & $\begin{array}{l}\text { Razvojni organ } \\
\text { proizvođača }\end{array}$ & A \\
\hline 3. & $\begin{array}{l}\text { Utvrđivanje potreba i mogućnosti ugradnje i } \\
\text { cuvanja }\end{array}$ & " & $"$ & B \\
\hline 4. & Predlaganje početnog koncepta održavanja & $\begin{array}{l}\text { Razvojni organ } \\
\text { proizvođaca }\end{array}$ & - & A \\
\hline 5. & $\begin{array}{l}\text { Određivanje klimatskih i mehanickkih uslova } \\
\text { održavanja }\end{array}$ & $n$ & $\begin{array}{l}\text { Razvojni organ } \\
\text { kupca }\end{array}$ & $\mathrm{C}$ \\
\hline 6. & $\begin{array}{l}\text { Definisanje parametara logisticke podrške u } \\
\text { okviru pođetnih TEZ }\end{array}$ & $\begin{array}{l}\text { Razvojni orga- } \\
\text { ni proizvođača } \\
\text { i kupca }\end{array}$ & - & A \\
\hline 7. & $\begin{array}{l}\text { Analiza mogucnosti obezbeđenja kadra za } \\
\text { rukovanje i održavanje }\end{array}$ & * & - & A \\
\hline 8. & $\begin{array}{l}\text { Propisivanje klimatskih i mehaničkih uslova } \\
\text { eksploatacije }\end{array}$ & $\begin{array}{l}\text { Razvojni organ } \\
\text { kupca }\end{array}$ & - & B \\
\hline 9. & $\begin{array}{l}\text { Utvrđivanje problematike logisticke podrske } \\
\text { koja mora biti rešena u okviru programa } \\
\text { realizacije (u daljem tekstu: PR) }\end{array}$ & $\begin{array}{l}\text { Razvojni organ } \\
\text { proizvođaca }\end{array}$ & - & A \\
\hline
\end{tabular}

Tabela 3

Aktivnosti koje se realizuju u okviru ugovaranja izrade programa realizacije

\begin{tabular}{|c|c|c|c|c|}
\hline $\begin{array}{c}\text { Redni } \\
\text { broj }\end{array}$ & \multicolumn{1}{|c|}{ Naziv aktivnosti } & $\begin{array}{c}\text { Nosilac } \\
\text { realizacije }\end{array}$ & Sarađuje & $\begin{array}{c}\text { Obaveznost } \\
\text { primene }\end{array}$ \\
\hline 1 & 2 & 3 & 4 & 5 \\
\hline 1. & $\begin{array}{l}\text { Analiza PA, a posebno zahteva pođetnih TEZ } \\
\text { po logistickoj podrści }\end{array}$ & $\begin{array}{l}\text { Planirani nosi- } \\
\text { lac izrade PR }\end{array}$ & - & $\mathrm{A}$ \\
\hline 2. & Definisanje ponude za izradu PR & $\begin{array}{l}\text { Planirani nosi- } \\
\text { lac izrade PR }\end{array}$ & - & $\mathrm{A}$ \\
\hline
\end{tabular}


Aktivnosti koje se realizuju u okviru izrade programa realizacije

\begin{tabular}{|c|c|c|c|c|}
\hline $\begin{array}{c}\text { Redni } \\
\text { broj }\end{array}$ & Naziv aktivnosti & $\begin{array}{l}\text { Nosilac } \\
\text { realizacije }\end{array}$ & Saraduje & $\begin{array}{l}\text { Obaveznost } \\
\text { primene }\end{array}$ \\
\hline 1 & 2 & 3 & 4 & 5 \\
\hline 1. & $\begin{array}{l}\text { Određivanje detaljnije razrađenog predloga } \\
\text { sastava tehnickog sistema i organizacijskih } \\
\text { rešenja njegovog korišenja }\end{array}$ & $\begin{array}{l}\text { Nosilac izrade } \\
\text { PR }\end{array}$ & $\begin{array}{l}\text { Razvojni organ } \\
\text { kupca }\end{array}$ & A \\
\hline 2. & $\begin{array}{l}\text { Utvrđivanje modela (koncepta) eksploatacije } \\
\text { u Životnom veku tehnickog sistema }\end{array}$ & $\begin{array}{l}\text { Nosilac izrade } \\
\text { PR }\end{array}$ & $"$ & A \\
\hline 3. & $\begin{array}{l}\text { Analiza moguénosti obezbeđenja kadra za } \\
\text { eksploataciju i održavanje }\end{array}$ & $\begin{array}{l}\text { Nosilac izrade } \\
\text { PR }\end{array}$ & $\begin{array}{l}\text { Razvojni organi } \\
\text { kupca i } \\
\text { proizvođaca }\end{array}$ & B \\
\hline 4. & $\begin{array}{l}\text { Analiza mogućnosti uklapanja u postojeću } \\
\text { podršku u održavanju u konkretnom poslov- } \\
\text { nom sistemu }\end{array}$ & $\begin{array}{l}\text { Nosilac izrade } \\
\text { PR }\end{array}$ & $\begin{array}{l}\text { Razvojni organi } \\
\text { proizvođaca }\end{array}$ & A \\
\hline 5. & $\begin{array}{l}\text { Utvrđivanje konačnog koncepta održavanja u } \\
\text { veku trajanja tehnickog sistema }\end{array}$ & $\begin{array}{l}\text { Nosilac izrade } \\
\text { PR }\end{array}$ & * & A \\
\hline 6. & $\begin{array}{l}\text { Prethodna procena i optimizacija očekivanih } \\
\text { troskkova životnog veka (radi eventualne ko- } \\
\text { rekcije koncepta održavanja i zahteva po logi- } \\
\text { stickoj podrsci) }\end{array}$ & $\begin{array}{l}\text { Nosilac izrade } \\
\text { PR }\end{array}$ & (1) & A \\
\hline 7. & $\begin{array}{l}\text { Određivanje konačnih TEZ po logistickoj } \\
\text { podrści }\end{array}$ & $\begin{array}{l}\text { Nosilac izrade } \\
\text { PR }\end{array}$ & $\begin{array}{l}\text { Razvojni organi } \\
\text { proizvođaca i } \\
\text { kupca }\end{array}$ & A \\
\hline 8. & $\begin{array}{l}\text { Definisanje principa projektovanja i provere } \\
\text { projektnih rešenja - sa stanovista logisticke } \\
\text { podrske }\end{array}$ & $\begin{array}{l}\text { Nosilac izrade } \\
\text { PR }\end{array}$ & $\begin{array}{l}\text { Razvojni organi } \\
\text { proizvođača }\end{array}$ & B \\
\hline 9. & Definisanje principa proizvodnje & $\begin{array}{l}\text { Nosilac izrade } \\
\text { PR }\end{array}$ & $\begin{array}{l}\text { Potencijalni pro- } \\
\text { izvodač i kontrola } \\
\text { kvaliteta }\end{array}$ & $\mathrm{C}$ \\
\hline 10. & $\begin{array}{l}\text { Utvrđivanje potreba za ispitivanjima u realnim } \\
\text { uslovima upotrebe }\end{array}$ & $\begin{array}{l}\text { Nosilac izrade } \\
\text { PR }\end{array}$ & $\begin{array}{l}\text { Razvojni organi } \\
\text { proizvođač i } \\
\text { kupca }\end{array}$ & B \\
\hline 11. & $\begin{array}{l}\text { Propisivanje zahteva u vezi konstrukcione, } \\
\text { tehnološke i tehničke dokumentacije za održa- } \\
\text { vanje }\end{array}$ & $\begin{array}{l}\text { Nosilac izrade } \\
\text { PR }\end{array}$ & $\begin{array}{l}\text { Razvojni organi } \\
\text { potencijalnog } \\
\text { proizvođača }\end{array}$ & A \\
\hline 12. & $\begin{array}{l}\text { Procene potreba za obuku kadra u vezi proi- } \\
\text { zvodnje i održavanja }\end{array}$ & $\begin{array}{l}\text { Nosilac izrade } \\
\text { PR }\end{array}$ & $\begin{array}{l}\text { Razvojni organi } \\
\text { kupca i } \\
\text { proizvođača }\end{array}$ & $\mathrm{C}$ \\
\hline 13. & $\begin{array}{l}\text { Određivanje neophodnih kontrolnih aktivno- } \\
\text { sti kupca }\end{array}$ & $\begin{array}{l}\text { Nosilac izrade } \\
\text { PR }\end{array}$ & $\begin{array}{l}\text { Razvojni organi } \\
\text { proizvodaca }\end{array}$ & B \\
\hline 14. & $\begin{array}{l}\text { Predlaganje plana zadataka za obezbeđenje } \\
\text { logisticke podrske u toku projektovanja i raz- } \\
\text { voja }\end{array}$ & $\begin{array}{l}\text { Nosilac izrade } \\
\text { PR }\end{array}$ & $n$ & A \\
\hline
\end{tabular}

(1) - Institucija osposobljena za procenu ifi proračun troskova żivotnog veka proizvoda 
Aktivnosti koje se realizuju u toku ugovaranja projektovanja i razvoja

\begin{tabular}{|c|c|c|c|c|}
\hline $\begin{array}{c}\text { Redni } \\
\text { broj }\end{array}$ & Naziv aktivnosti & $\begin{array}{l}\text { Nosilac } \\
\text { realizacije }\end{array}$ & Sarađuje & $\begin{array}{l}\text { Obaveznost } \\
\text { primene }\end{array}$ \\
\hline 1 & 2 & 3 & 4 & 5 \\
\hline 1. & $\begin{array}{l}\text { Analiza PR (a posebno zahteva po logistickkoj } \\
\text { podršci i plana zadataka za obezbeđenje te } \\
\text { podrske) sa procenom njihove realnosti i mo- } \\
\text { guénosti ispunjenja }\end{array}$ & $\begin{array}{l}\text { Potencijalni } \\
\text { izvođac }\end{array}$ & - & $\bar{A}$ \\
\hline 2. & Izrada ponude za projektovanje i razvoj & $\begin{array}{l}\text { Potencijalni } \\
\text { izvodac }\end{array}$ & - & A \\
\hline 3. & $\begin{array}{l}\text { Procena troškova Životnog veka prethodno } \\
\text { sagledanog konstrukcionog reß̌enja }\end{array}$ & $\begin{array}{l}\text { Potencijalni } \\
\text { izvođač }\end{array}$ & - & B \\
\hline 4. & $\begin{array}{l}\text { Analiza ponuda i procena troškova životnog } \\
\text { veka }\end{array}$ & $(2)+(1)$ & - & A \\
\hline 5. & $\begin{array}{l}\text { Razjašnjavanje i usaglašavanje nedoređenih ili } \\
\text { suprotnih gledišta kupca i potencijalnih izvo- } \\
\text { đaca }\end{array}$ & $\begin{array}{l}\text { Stručna komi- } \\
\text { sija kupca }\end{array}$ & - & B \\
\hline 6. & $\begin{array}{l}\text { Dopunjavanje ili izmena ponude ili procene } \\
\text { troskkova veka }\end{array}$ & $\begin{array}{l}\text { Potencijalni } \\
\text { izvođač }\end{array}$ & - & A \\
\hline 7. & Sklapanje ugovora za projektovanje i razvoj & $\begin{array}{l}\text { Komercijala } \\
\text { kupca i } \\
\text { prodavca }\end{array}$ & - & B \\
\hline
\end{tabular}

(1) - Institucija osposobljena za procenu i proracun troškova Zivotnog veka tehnickog sistema

(2) - Stručna komisija kupca

Tabela 6

Aktivnosti koje se realizuju u toku izrade idejnog projekta ili pretprojekta

\begin{tabular}{|c|c|c|c|c|}
\hline $\begin{array}{c}\text { Redni } \\
\text { broj }\end{array}$ & Naziv aktivnosti & $\begin{array}{l}\text { Nosilac } \\
\text { realizacije }\end{array}$ & Sarađuje & $\begin{array}{l}\text { Obaveznost } \\
\text { primene }\end{array}$ \\
\hline 1 & 2 & 3 & 4 & 5 \\
\hline 1. & $\begin{array}{l}\text { Sagledavanje obaveza rukovodecih struktura } \\
\text { i određivanje neposredno odgovornih za rea- } \\
\text { lizaciju programa logisticke podrške }\end{array}$ & $\begin{array}{l}\text { Upravna } \\
\text { struktura izvo- } \\
\text { đaça idejnog } \\
\text { projekta }\end{array}$ & - & A \\
\hline 2. & $\begin{array}{l}\text { Razmatranje tehnið̌kih i tehnoloških rě̌enja } \\
\text { postojecih tehnickkih sistema koji obavljaju } \\
\text { istu ili sličnu funkciju }\end{array}$ & $\begin{array}{l}\text { Rukovodilac } \\
\text { idejnog } \\
\text { projekta }\end{array}$ & - & B \\
\hline 3. & Definisanje projektne zamishi & $\begin{array}{l}\text { Rukovodilac } \\
\text { idejnog } \\
\text { projekta }\end{array}$ & - & A \\
\hline 4. & $\begin{array}{l}\text { Izrada funkcionalne blok-Seme sistema ili slo- } \\
\text { ženog tehnickog sredstva sa predlaganjem kri- } \\
\text { terijuma za ocenu uslova otkaza sistema }\end{array}$ & $\begin{array}{l}\text { Projektantski } \\
\text { tim }\end{array}$ & - & A \\
\hline 5. & $\begin{array}{l}\text { Raščlanjivanje TEZ za tehnički sistem na } \\
\text { zahteve koje treba da ispune pojedinačna } \\
\text { sredstva (podsistemi) ovog sistema }\end{array}$ & $\begin{array}{l}\text { Projektantski } \\
\text { tim }\end{array}$ & - & A \\
\hline 6. & $\begin{array}{l}\text { Definisanje dopunskih zahteva kojima se obe- } \\
\text { zbeđuje međusobna usklađenost i neometanje } \\
\text { rada uzajamno spregnutih tehnickih sredstava } \\
\text { i agregata (podsistema) }\end{array}$ & $\begin{array}{l}\text { Projektantski } \\
\text { tim }\end{array}$ & - & A \\
\hline
\end{tabular}




\begin{tabular}{|c|c|c|c|c|}
\hline 1 & 2 & 3 & 4 & 5 \\
\hline 7. & $\begin{array}{l}\text { Definisanje pojedinačnih projektnih zadataka } \\
\text { za svako sredstvo ili agregat projektovanog } \\
\text { tehnickog sistema, odnosno projektnih zada- } \\
\text { taka za izradu softvera }\end{array}$ & $\begin{array}{l}\text { Rukovodilac } \\
\text { idejnog } \\
\text { projekta }\end{array}$ & - & A \\
\hline 8. & $\begin{array}{l}\text { Procena da li je operativno, tehnicki i eko- } \\
\text { nomski opravdano da se pojedine funkcije } \\
\text { tehničkog sistema rese putem nabavke ili } \\
\text { kopiranja rešenja već gotovih tehničkih sred- } \\
\text { stava ili agregata, odnosno softverskih proi- } \\
\text { zvoda, ili putem projektovanja u drugim spe- } \\
\text { cijalizovanim projektantskim organizacijama }\end{array}$ & $\begin{array}{l}\text { Projektantski } \\
\text { tim }\end{array}$ & - & B \\
\hline 9. & $\begin{array}{l}\text { Zakljucivanje ugovora sa drugim projektant- } \\
\text { skim organizacijama (eventualno) }\end{array}$ & $\begin{array}{l}\text { Rukovodilac } \\
\text { idejnog } \\
\text { projekta }\end{array}$ & $\begin{array}{l}\text { Ekonomski sektor } \\
\text { izvođaca idejnog } \\
\text { projekta }\end{array}$ & C \\
\hline 10. & $\begin{array}{l}\text { Proučavanje projektnih zadataka od strane } \\
\text { projektanata ili projektantskih grupa }\end{array}$ & $\begin{array}{l}\text { Idejni projek- } \\
\text { tant odrede- } \\
\text { nog sredstva }\end{array}$ & - & A \\
\hline 11. & $\begin{array}{l}\text { Revizija projektne zamisli i zadataka za idejno } \\
\text { projektovanje pojedinačnih sredstava, agre- } \\
\text { gata i softvera razvijenog tehničkog sistema ili } \\
\text { složenog sredstva }\end{array}$ & $\begin{array}{l}\text { Predsednik } \\
\text { komisije za } \\
\text { reviziju pro- } \\
\text { jektne zamisli } \\
\text { i zadataka } \\
\end{array}$ & - & A \\
\hline 12. & $\begin{array}{l}\text { Idejno projektovanje pojedinačnih tehnickih } \\
\text { sredstava i agregata i neophodnog softvera }\end{array}$ & $\begin{array}{l}\text { Idejni projek- } \\
\text { tant određe- } \\
\text { nog sredstva }\end{array}$ & - & A \\
\hline 13. & $\begin{array}{l}\text { Integracija projekata pojedinačnih sredstava } \\
\text { u projekat tehnickog sistema sa usklađivanjem } \\
\text { međusobno oprečnih rešenja iz idejnih proje- } \\
\text { kata (odnosno pretprojekata) pojedinačnih } \\
\text { sredstava }\end{array}$ & $\begin{array}{l}\text { Rukovodilac } \\
\text { idejnog } \\
\text { projekta }\end{array}$ & $\begin{array}{l}\text { Projektanti } \\
\text { pojedinačnih } \\
\text { sredstava }\end{array}$ & $\bar{A}$ \\
\hline 14. & $\begin{array}{l}\text { Izrada matematickih modela funkcionisanja } \\
\text { tehničkog sistema sa simulacijom kako ce ovaj } \\
\text { sistem u razlicitim ekstremno nepovoljnim } \\
\text { uslovima upotrebe izvršavati svoj zadatak }\end{array}$ & $\begin{array}{l}\text { Stručnjaci } \\
\text { osposobljeni } \\
\text { za izradu } \\
\text { matematickih } \\
\text { modela i } \\
\text { simulaciju } \\
\end{array}$ & $\begin{array}{l}\text { Idejni projektanti } \\
\text { sistema }\end{array}$ & $\bar{C}$ \\
\hline 15. & $\begin{array}{l}\text { Procena troškova životnog veka predviđene } \\
\text { varijante idejnog rešenja }\end{array}$ & $\begin{array}{l}\text { Projektantski } \\
\text { tim }\end{array}$ & (1) & $\mathrm{B}$ \\
\hline 16. & $\begin{array}{l}\text { Procena da li ce se idejnim projektom (odno- } \\
\text { sno pretprojektom) predloženi tehnixki sistem } \\
\text { i njegova sredstva uklopiti u propisani koncept } \\
\text { odrzavanja }\end{array}$ & \begin{tabular}{|l|} 
Stručnjak od- \\
govoran za \\
realizaciju lo- \\
gisticke \\
podrške \\
\end{tabular} & $\begin{array}{l}\text { Idejni projektanti } \\
\text { sredstava }\end{array}$ & A \\
\hline 17. & $\begin{array}{l}\text { Procena da li ce idejnim projektom (odnosno } \\
\text { pretprojektom) predloženih tehnickih sistema } \\
\text { i njegovih sredstava zadovoljiti propisani TEZ } \\
\text { u vezi s logistickom podrskom }\end{array}$ & $\begin{array}{l}\text { Rukovodilac } \\
\text { idejnog } \\
\text { projekta }\end{array}$ & $\begin{array}{l}\text { Idejni projektanti } \\
\text { sredstava }\end{array}$ & A \\
\hline 18. & $\begin{array}{l}\text { Upotpunjavanje ili menjanje TEZ zahteva } \\
\text { sagledanih u toku radova na idejnom projektu }\end{array}$ & \begin{tabular}{|l|} 
Rukovodilac \\
idejnog \\
projekta \\
\end{tabular} & - & A \\
\hline 19. & Prijem idejnog projekta (ili pretprojekta) & $\begin{array}{l}\text { Stručna komi- } \\
\text { sija kupca }\end{array}$ & - & A \\
\hline 20. & Usvajanje idejnog projekta (ili pretprojekta) & $\begin{array}{l}\text { Odgovarajuci } \\
\text { nivo odluciva- } \\
\text { nja }\end{array}$ & - & A \\
\hline
\end{tabular}

(1) - Institucija osposobljena za procenu ili proračun trołkova zivotnog veka proizwoda 
Aktivnosti koje se realizuju u toku izrade detaljnog projekta

\begin{tabular}{|c|c|c|c|c|}
\hline $\begin{array}{c}\text { Redni } \\
\text { broj }\end{array}$ & Naziv aktivnosti & $\begin{array}{l}\text { Nosilac } \\
\text { realizacije }\end{array}$ & Sarađuje & $\begin{array}{c}\text { Obaveznost } \\
\text { primene }\end{array}$ \\
\hline 1 & 2 & 3 & 4 & 5 \\
\hline 1. & $\begin{array}{l}\text { Sagledavanje obaveza rukovodecih struktura } \\
\text { i odredivanje neposredno odgovornih za rea- } \\
\text { lizaciju pojedinih delova i integraciju pro- } \\
\text { grama logisticke podrske }\end{array}$ & $\begin{array}{l}\text { Upravna } \\
\text { struktura } \\
\text { izvođača } \\
\text { projekta } \\
\end{array}$ & - & $\mathbf{A}$ \\
\hline 2. & $\begin{array}{l}\text { Razmatranje tehnickih i tehnoloških rełenja } \\
\text { postojecih tehnickih sredstava i agregata koji } \\
\text { obavljaju istu ili sličnu funkciju (ako to vec } \\
\text { nije učnjeno u okviru idejnog projekta) }\end{array}$ & $\begin{array}{l}\text { Projektanti } \\
\text { sredstva }\end{array}$ & - & B \\
\hline 3. & $\begin{array}{l}\text { Definisanje projektne zamisli tehničkog sred- } \\
\text { stva (ako to vec nije učinjeno u okviru idejnog } \\
\text { projekta) }\end{array}$ & $\begin{array}{l}\text { Projektanti } \\
\text { sredstva }\end{array}$ & - & A \\
\hline 4. & $\begin{array}{l}\text { Izrada funkcionalne blok-šeme tehnickkog } \\
\text { sredstva (ukoliko to već nije učinjeno u okviru } \\
\text { idejnog projekta) }\end{array}$ & $\begin{array}{l}\text { Projektanti } \\
\text { sredstva }\end{array}$ & - & A \\
\hline 5. & $\begin{array}{l}\text { Odredivanje modela pouzdanosti koji odgo- } \\
\text { vara predvidenom konstrukcionom resenju i } \\
\text { nacinu eksploatacije tehničkog sredstva }\end{array}$ & $\begin{array}{l}\text { Stručnjaci za } \\
\text { pouzdanost }\end{array}$ & - & A \\
\hline 6. & $\begin{array}{l}\text { Rašllanjivanje TEZ za tehnickki sistem, sred- } \\
\text { stvo ili agregat na zahteve koje treba da } \\
\text { ispune njegovi sklopovi ili podsklopovi (uko- } \\
\text { liko to već nije ucinjeno u okviru idejnog } \\
\text { projekta) }\end{array}$ & $\begin{array}{l}\text { Projektanti } \\
\text { sredstva }\end{array}$ & - & A \\
\hline 7. & $\begin{array}{l}\text { Definisanje dopunskih zahteva kojima se obe- } \\
\text { zbeđuju međusobna usklađivanja i neometa- } \\
\text { nje rada uzajamno spregnutih sklopova i pods- } \\
\text { klopova (ukoliko to vec nije ucinjeno u okviru } \\
\text { idejnog projekta) }\end{array}$ & $\begin{array}{l}\text { Projektanti } \\
\text { sredstva }\end{array}$ & - & A \\
\hline 8. & $\begin{array}{l}\text { Utvrđivanje pojedinačnih projektnih zadataka } \\
\text { za svaki sklop ili podsklop projektovanog } \\
\text { tehnickog sredstva, odnosno deo projektova- } \\
\text { nog softverskog proizvoda }\end{array}$ & $\begin{array}{l}\text { Projektanti } \\
\text { sredstva }\end{array}$ & - & A \\
\hline 9. & $\begin{array}{l}\text { Procena da li je operativno, tehnicki i eko- } \\
\text { nomski opravdano da se umesto sopstvenog } \\
\text { razvoja pojedinog sklopa, podsklopa ili dela } \\
\text { softverskog proizvoda on projektuje u nekoj } \\
\text { specijalizovanoj projektantskoj organizaciji ili } \\
\text { nabavi kao gotov proizvod }\end{array}$ & $\begin{array}{l}\text { Projektanti } \\
\text { sredstva }\end{array}$ & 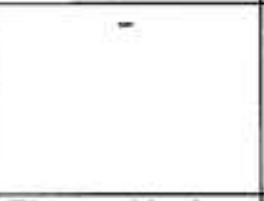 & $\mathrm{C}$ \\
\hline 10. & $\begin{array}{l}\text { Zakljucivanje ugovora sa drugim projektant- } \\
\text { skim organizacijama }\end{array}$ & $\begin{array}{l}\text { Projektanti } \\
\text { sredstva }\end{array}$ & $\begin{array}{l}\text { Ekonomski sektor } \\
\text { izvođaca projekta }\end{array}$ & $\mathrm{C}$ \\
\hline 11. & Proučavanje zadataka od strane projektanata & $\begin{array}{l}\text { Projektanti } \\
\text { sklopova, } \\
\text { podsklopova i } \\
\text { softvera } \\
\end{array}$ & - & A \\
\hline 12. & $\begin{array}{l}\text { Revizija projektne zamisli i zadataka za de- } \\
\text { taljno projektovanje pojedinačnih sklopova } \\
\text { razmatranog tehničkog sredstva }\end{array}$ & $\begin{array}{l}\text { Predsednik } \\
\text { komisije za re- } \\
\text { viziju projek- } \\
\text { tne zamisli i } \\
\text { zadatka } \\
\end{array}$ & - & A \\
\hline 13. & $\begin{array}{l}\text { Hardversko i softversko projektovanje sklo- } \\
\text { pova i podsklopova }\end{array}$ & $\begin{array}{l}\text { Projektanti } \\
\text { sklopova, } \\
\text { podsklopova i } \\
\text { softvera } \\
\end{array}$ & - & A \\
\hline
\end{tabular}




\begin{tabular}{|c|c|c|c|c|}
\hline 1 & 2 & 3 & 4 & 5 \\
\hline 14. & $\begin{array}{l}\text { Integracija projekata pojedinačnih sklopova i } \\
\text { podsklopova u projekat tehnickog sistema ili } \\
\text { agregata, sa uskladivanjem eventualno opreč- } \\
\text { nih zahteva iz projekta ovih sklopova }\end{array}$ & $\begin{array}{l}\text { Projektanti } \\
\text { sredstva }\end{array}$ & $\begin{array}{l}\text { Projektanti sklo- } \\
\text { pova, podsklopo- } \\
\text { va i softvera }\end{array}$ & $\bar{A}$ \\
\hline 15. & $\begin{array}{l}\text { Izrada matematickog modela funkcionisanja } \\
\text { sa simulacijom funkcije sredstava u ekstremno } \\
\text { nepovoljnim uslovima upotrebe }\end{array}$ & \begin{tabular}{|l} 
Stručnjaci \\
osposobljeni \\
za izradu ma- \\
tematickih \\
modela i simu- \\
laciju \\
\end{tabular} & $\begin{array}{l}\text { Projektant } \\
\text { sredstva }\end{array}$ & $\mathrm{C}$ \\
\hline 16. & $\begin{array}{l}\text { Procena da li ce se projektovano sredstvo, } \\
\text { odnosno agregat, uklopiti u predvideni kon- } \\
\text { cept održavanja }\end{array}$ & $\begin{array}{l}\text { Stručnjak od- } \\
\text { govoran za } \\
\text { realizaciju lo- } \\
\text { gisticke podr- } \\
\text { Ske }\end{array}$ & $\begin{array}{l}\text { Projektanti } \\
\text { sredstva }\end{array}$ & A \\
\hline 17. & $\begin{array}{l}\text { Procena da li ce projektovano sredstvo, odno- } \\
\text { sno agregat, zadovoljiti sve postavljene za- } \\
\text { hteve u vezi s logistickom podrskom }\end{array}$ & $\begin{array}{l}\text { Projektanti } \\
\text { sredstva }\end{array}$ & $\begin{array}{l}\text { Projektanti sklo- } \\
\text { pova, podsklopo- } \\
\text { va i softvera }\end{array}$ & A \\
\hline 18. & $\begin{array}{l}\text { Procena troß̌kova životnog veka razrađene } \\
\text { projektne varijante sa predlogom njihove op- } \\
\text { timizacije }\end{array}$ & $\begin{array}{l}\text { Projektanti } \\
\text { sklopova, } \\
\text { podsklopova, i } \\
\text { softvera }\end{array}$ & (1) & A \\
\hline 19. & $\begin{array}{l}\text { Izrada neophodne KD, a eventualno i tehno- } \\
\text { loske dokumentacije (u daljem tekstu: ThD) }\end{array}$ & Projektanti & - & A \\
\hline 20. & $\begin{array}{l}\text { Izrada prednacrta propisa o kvalitetu proi- } \\
\text { zvoda (PKP) za razvoj prototipa sredstva, } \\
\text { odnosno agregata }\end{array}$ & $\begin{array}{l}\text { Projektanti } \\
\text { sredstva }\end{array}$ & $\begin{array}{l}\text { Stručnjaci odgo- } \\
\text { vorni za realiza- } \\
\text { ciju logisticke } \\
\text { podrske }\end{array}$ & A \\
\hline 21. & $\begin{array}{l}\text { Izrada zahteva za nabavku i ispitivanje sklopo- } \\
\text { va, podsklopova, delova softverskih proizvoda } \\
\text { i nestandardnih s/d koji se kupuju od drugih } \\
\text { isporucilaca }\end{array}$ & Projektanti & - & B \\
\hline 22. & Prijem detaljnog projekta & $\begin{array}{l}\text { Struěna komi- } \\
\text { sija kupca ili } \\
\text { projektanta }\end{array}$ & - & A \\
\hline 23. & Usvajanje detaljnog projekta & $\begin{array}{l}\text { Odgovarajuć } \\
\text { nivo odlučiva- } \\
\text { nja }\end{array}$ & - & - \\
\hline
\end{tabular}

(1) - Institucija osposobljena za procenu ili proračun troßkova zivotnog veka proizvoda.

Tabela 8

Aktivnosti koje se realizuju u toku izrade funkcionalnog modela ili probnog komada

\begin{tabular}{|c|c|c|c|c|}
\hline $\begin{array}{c}\text { Redni } \\
\text { broj }\end{array}$ & \multicolumn{1}{|c|}{ Naziv aktivnosti } & $\begin{array}{c}\text { Nosilac } \\
\text { realizacije }\end{array}$ & Sarađuje & $\begin{array}{c}\text { Obaveznost } \\
\text { primene }\end{array}$ \\
\hline 1 & 2 & 3 & 4 & 5 \\
\hline 1. & $\begin{array}{l}\text { Određivanje neposredno odgovornih za reali- } \\
\text { zaciju pojedinih delova i integraciju programa } \\
\text { logisticke podrśke }\end{array}$ & $\begin{array}{l}\text { Upravna } \\
\text { struktura no- } \\
\text { sioca razvoja }\end{array}$ & - & $\mathrm{A}$ \\
\hline 2. & $\begin{array}{l}\text { Nabavka sklopova, podsklopova i nestandar- } \\
\text { dnih s/d ili delova softverskih proizvoda koji } \\
\text { se kupuju od drugih isporučilaca }\end{array}$ & $\begin{array}{l}\text { Nabavni orga- } \\
\text { ni nosioca } \\
\text { razvoja }\end{array}$ & $\begin{array}{l}\text { Služba obezbeđe- } \\
\text { nja kvaliteta nosi- } \\
\text { oca razvoja proiz- } \\
\text { vođača i kupca }\end{array}$ & $\mathrm{C}$ \\
\hline 3. & $\begin{array}{l}\text { Materijalizacija i provera funkcionisanja svih } \\
\text { podsklopova i sklopova tehnickih sistema ili } \\
\text { sredstya }\end{array}$ & $(3)$ & - & $\mathrm{A}$ \\
\hline
\end{tabular}




\begin{tabular}{|c|c|c|c|c|}
\hline 1 & 2 & 3 & 4 & 5 \\
\hline 4. & Proračun - procena pouzdanosti & $\begin{array}{l}\text { Specijalisti za } \\
\text { proracun pou- } \\
\text { zdanosti }\end{array}$ & - & $\bar{B}$ \\
\hline 5. & $\begin{array}{l}\text { Provera mogućnosti jednostavnog podešava- } \\
\text { nja i defektacije svih podsklopova i sklopova }\end{array}$ & (3) & - & A \\
\hline 6. & $\begin{array}{l}\text { Integracija funkcionalnog modela ili probnog } \\
\text { komada }\end{array}$ & (4) & - & A \\
\hline 7. & $\begin{array}{l}\text { Provera stabilnosti sirovina, repromaterijala } \mathrm{i} \\
\text { s/d cije karakteristike degradiraju u toku vre- } \\
\text { mena }\end{array}$ & (5) & - & $\mathbf{A}$ \\
\hline 8. & Interna provera zadovoljenja prednacrta PKP & (5) & (4) & A \\
\hline 9. & $\begin{array}{l}\text { Razmatranje potrebe da se za eksploataciju i } \\
\text { odrzavanje projektovanog tehnickog sredstva } \\
\text { razviju specijalna remontna oprema, nastavna } \\
\text { sredstva i individualni i grupni kompleti rezer- } \\
\text { vnih delova (u daljem tekstu: r/d, alata i } \\
\text { pribora) }\end{array}$ & (6) & $\begin{array}{l}\text { Odgovarajući } \\
\text { projektanti }\end{array}$ & B \\
\hline 10. & $\begin{array}{l}\text { Formulisanje plana zadataka kojima se obe- } \\
\text { zbeđuje ugradnja svih zahteva prednacrta PKP } \\
\text { koje jos uvek ne zadovoljava funkcionalni } \\
\text { model, a mora zadovoljiti PT }\end{array}$ & (7) & - & A \\
\hline 11. & $\begin{array}{l}\text { Prijem i usvajanje funkcionalnog modela sa } \\
\text { donošenjem predloga za dalji rad }\end{array}$ & (8) & - & A \\
\hline
\end{tabular}

gde je:

(3) - Stručnjaci zaduženi za izradu (materijalizaciju) sklopova i podsklopova

(4) - Strucnjaci zaduseni za integraciju funkeionalnog modela, probnog komada ili PT

(5) - Ispitna laboratorija nosioca raxvoja ili osposobljena ispitna laboratorija

(6) - Stručnjak zadužten za obezbeđenje pogodnosti za održavanje i strućnjaci za obezbeđenje obuke

(7) - Koordinator zadataka na izradi funkcionalnog modela, probnog komada ili PT

(8) - Komisija nosioca razvoja koja obavlja prijem i usvajanje funkcionalnog modela (ili probnog komada)

Tabela 9

Aaktivnosti koje se realizuju u toku izrade prototipa (PT) ili prototipske partije (PP)

\begin{tabular}{|c|c|c|c|c|}
\hline $\begin{array}{c}\text { Redni } \\
\text { broj }\end{array}$ & Naziv aktivnosti & $\begin{array}{l}\text { Nosilac } \\
\text { realizacije }\end{array}$ & Sarađuje & $\begin{array}{l}\text { Obaveznost } \\
\text { primene }\end{array}$ \\
\hline 1 & 2 & 3 & 4 & 5 \\
\hline 1. & $\begin{array}{l}\text { Odredivanje neposredno odgovornih za reali- } \\
\text { zaciju pojedinih delova i integraciju programa } \\
\text { logisticke podrske }\end{array}$ & $\begin{array}{l}\text { Upravna } \\
\text { struktura no- } \\
\text { sioca razvoja }\end{array}$ & - & A \\
\hline 2. & $\begin{array}{l}\text { Nabavka sklopova, nestandardnih s/d ili de- } \\
\text { lova softverskih proizvoda koji se kupuju od } \\
\text { drugih proizvodaca }\end{array}$ & $\begin{array}{l}\text { Nabavni or- } \\
\text { gani nosioca } \\
\text { razvoja }\end{array}$ & $\begin{array}{l}\text { Služba obezbeđe- } \\
\text { nja kvaliteta no- } \\
\text { sioca razvoja }\end{array}$ & $\mathrm{C}$ \\
\hline 3. & $\begin{array}{l}\text { Materijalizacija i provera funkcionisanja svih } \\
\text { podsklopova i sklopova tehnickog sredstva }\end{array}$ & (3) & - & A \\
\hline 4. & Proračun - procena pouzdanosti* & $\begin{array}{l}\text { Stručnjaci za } \\
\text { proracun pou- } \\
\text { zdanosti }\end{array}$ & - & A \\
\hline 5. & $\begin{array}{l}\text { Provera mogućnosti jednostavnog podesava- } \\
\text { nja i defektacije svih podsklopova i sklopova }\end{array}$ & (3) & - & A \\
\hline 6. & Integracija PT & (5) & (4) & A \\
\hline 7. & $\begin{array}{l}\text { Provera stabilnosti sirovina, repromaterijala i } \\
\text { s/d cije karakteristike degradiraju u toku vre- } \\
\text { mena* }\end{array}$ & (5) & - & A \\
\hline
\end{tabular}




\begin{tabular}{|c|c|c|c|c|}
\hline 1 & 2 & 3 & 4 & 5 \\
\hline 8. & Interna provera zadovoljenja prednacrta PKP & (4) & - & A \\
\hline 9. & $\begin{array}{l}\text { Projektovanje i realizacija dorada kojima se } \\
\text { poboljSavaju nezadovoljavajuci rezultati in- } \\
\text { terne provere PT }\end{array}$ & (3) i (4) & - & B \\
\hline 10. & $\begin{array}{l}\text { Razmatranje potrebe da se za eksploataciju i } \\
\text { održavanje projektovanog tehnickog sredstva } \\
\text { razviju specijalna remontna oprema, objekti } \\
\text { infrastrukture, nastavna sredstva i individualni } \\
\text { i grupni kompleti r/d, alata ili pribora }\end{array}$ & $(6)$ & (3) $\mathrm{i}(4)$ & B \\
\hline 11. & $\begin{array}{l}\text { Projektovanje, izrada i provera elemenata } \\
\text { neophodne podrške u odrzavanju (ambalaže, } \\
\text { individualnog kompleta r/d, alata i pribora, a } \\
\text { eventualno, i sredstava i postupaka za even- } \\
\text { tualnu konzervaciju) }\end{array}$ & (3) & - & A \\
\hline 12. & $\begin{array}{l}\text { Izrada kompletne } \mathrm{KD} \text {, najneophodnije ThD i } \\
\text { privremenog Uputstva za rukovanje, osnovno } \\
\text { i tehnicko održavanje }\end{array}$ & $\begin{array}{l}\text { Stručnjaci za- } \\
\text { duženi za iz- } \\
\text { radu navedene } \\
\text { dokumentacije }\end{array}$ & (3) i (4) & A \\
\hline 13. & $\begin{array}{l}\text { Obuka kadra predviđenog za proveravanje } \\
\text { eksploatacije i tehničkog održavanja }\end{array}$ & $\begin{array}{l}\text { Stručnjaci koje } \\
\text { je odredio no- } \\
\text { silac razvoja }\end{array}$ & - & B \\
\hline 14. & Završna ispitivanja PT & $\begin{array}{l}\text { Nadležni kon- } \\
\text { trolni tehnixki } \\
\text { centar }\end{array}$ & $\begin{array}{l}\text { Razvojni organi } \\
\text { proizvodača i } \\
\text { kupca }\end{array}$ & A \\
\hline 15. & $\begin{array}{l}\text { Prijem i usvajanje PT sa donošenjem predloga } \\
\text { za dalji rad }\end{array}$ & $\begin{array}{l}\text { Odgovarajuci } \\
\text { nivo odluciva- } \\
\text { nja kupca }\end{array}$ & - & A \\
\hline
\end{tabular}

(3) - StruČnjaci zaduženi za izradu (materijalizaciju) sklopova i podsklopova

(4) - Strucnjaci zaduženi za integraciju funkcionalnog modela, probnog komada ili PT

(5) - Ispitna laboratorija nosioca razvoja ili osposobljena ispitna laboratorija

(6) - Strutnjak zadužen za obezbeđenje pogodnosti za održavanje i stručnjaci za obezbeđenje obuke

- Zadaci koji se ne realizuju u slučju da je materijalizaciji PT prethodila izrada funkcionalnog modela ili probnog komada

Tabela 10

Aktivnosti koje se realizuju u toku izrade funkcionalnog modela ili probnog komada

\begin{tabular}{|c|c|c|c|c|}
\hline $\begin{array}{c}\text { Redni } \\
\text { broj }\end{array}$ & Naziv aktivnosti & $\begin{array}{l}\text { Nosilac } \\
\text { realizacije }\end{array}$ & Sarađuje & $\begin{array}{l}\text { Obaveznost } \\
\text { primene }\end{array}$ \\
\hline 1 & 2 & 3 & 4 & 5 \\
\hline 1. & Izrada nacrta PKP & $\begin{array}{l}\text { Nosilac } \\
\text { razvoja }\end{array}$ & (9) & A \\
\hline 2. & $\begin{array}{l}\text { Izrada ponude za osvajanje proizvodnje (iz- } \\
\text { radu } 0^{+4} \text { serije) i serijsku proizvodnju sa } \\
\text { predlogom programa logisticke podrške, a } \\
\text { kojim treba garantovati zadovoljenje postav- } \\
\text { ljenih zahteva }\end{array}$ & $\begin{array}{l}\text { Potencijalni } \\
\text { proizvođač }\end{array}$ & - & A \\
\hline 3. & $\begin{array}{l}\text { Zakljucivanje ugovora za osvajanje proizvod- } \\
\text { nje (izradu }, 0^{4} \text { serije) i serijsku proizvodnju } \\
\text { tehnickog sredstva ili sistema }\end{array}$ & $\begin{array}{l}\text { Komercijala } \\
\text { kupca i } \\
\text { proizvođača }\end{array}$ & - & A \\
\hline
\end{tabular}

(9) - Radna grupa predstavnika zainteresovanih ustanova i proizvođađa koju saziva nosilac razvoja i nadležni organ za standardizaciju 
Aktivnosti koje se realizuju u toku izrade nulte serije

\begin{tabular}{|c|c|c|c|c|}
\hline $\begin{array}{c}\text { Redni } \\
\text { broj }\end{array}$ & Naziv aktivnosti & $\begin{array}{l}\text { Nosilac } \\
\text { realizacije }\end{array}$ & Sarađuje & $\begin{array}{l}\text { Obaveznost } \\
\text { primene }\end{array}$ \\
\hline 1 & 2 & 3 & 4. & 5 \\
\hline 1. & $\begin{array}{l}\text { Sagledavanje obaveza rukovodecih struktura } \\
\text { i odredivanje neposredno odgovornih za rea- } \\
\text { lizaciju programa logisticke podrške }\end{array}$ & $\begin{array}{l}\text { Upravna } \\
\text { struktura } \\
\text { proizvođača }\end{array}$ & $\overline{-}$ & $\bar{A}$ \\
\hline 2. & Dopunjavanje KD i izrada ThD & $(10)$ & - & A \\
\hline 3. & Aktivnosti službe obezbeđenja kvaliteta & $\begin{array}{l}\text { Služba obez- } \\
\text { beđenja } \\
\text { kvaliteta }\end{array}$ & - & A \\
\hline 4. & $\begin{array}{l}\text { Izrada PT specijalne remontne opreme i na- } \\
\text { stavnih sredstava }\end{array}$ & $\begin{array}{l}\text { Proizvodnja } \\
\text { odeljenja } \\
\text { proizvođača }\end{array}$ & - & A \\
\hline 5. & $\begin{array}{l}\text { Izrada konačne verzije Pravila za rukovanje i } \\
\text { osnovno održavanje, nacrta Uputstva za teh- } \\
\text { ničko održavanje, nacrta Uputstva za srednji } \\
\text { remont i nacrta Imenika s/d }\end{array}$ & $\begin{array}{l}\text { Stručnjaci za- } \\
\text { duženi za izra- } \\
\text { du navedene } \\
\text { dokumentacije }\end{array}$ & - & A \\
\hline 6. & $\begin{array}{l}\text { Davanje podataka za izradu normativa rezer- } \\
\text { vnih delova }\end{array}$ & $\begin{array}{l}\text { Razvojni tim } \\
\text { proizvođača }\end{array}$ & - & B \\
\hline 7. & $\begin{array}{l}\text { Propisivanje postupaka ispitivanja stabilnosti } \\
\text { tehnickog sredstva i sklopova cije karakteri- } \\
\text { stike degradiraju u toku vremena }\end{array}$ & $\begin{array}{l}\text { Razvojni tim } \\
\text { proizvođaca }\end{array}$ & $\begin{array}{l}\text { Služba obezbeđe- } \\
\text { nja kvaliteta }\end{array}$ & A \\
\hline 8. & $\begin{array}{l}\text { Obuka kadra za rukovanje, tehnicko održava- } \\
\text { nje, a, eventualno, i srednji remont }\end{array}$ & $\begin{array}{l}\text { Odabrani } \\
\text { stručnjaci } \\
\text { proizvođača }\end{array}$ & $\begin{array}{l}\text { Odabrani strux- } \\
\text { njaci drugih } \\
\text { isporucilaca }\end{array}$ & A \\
\hline 9. & $\begin{array}{l}\text { Interna provera pouzdanosti, trajnosti, pogod- } \\
\text { nosti za održavanje i troškova żivotnog veka }\end{array}$ & $\begin{array}{l}\text { Služba } \\
\text { obezbeđenja } \\
\text { kvaliteta }\end{array}$ & $\begin{array}{l}\text { Kadar remont- } \\
\text { nih jedinica i } \\
\text { ustanova }\end{array}$ & A \\
\hline 10. & $\begin{array}{l}\text { Nabavka rezervnih delova potrebnih za održa- } \\
\text { vanje „ } 0^{\prime \prime} \text { serije }\end{array}$ & $\begin{array}{l}\text { Komercijala } \\
\text { kupca }\end{array}$ & $\begin{array}{l}\text { Razvojni organ } \\
\text { kupca i } \\
\text { proizvođaca }\end{array}$ & B \\
\hline 11. & $\begin{array}{l}\text { Priprema kadra za održavanje u toku garan- } \\
\text { tnog roka }\end{array}$ & $\begin{array}{l}\text { Servisna } \\
\text { služba }\end{array}$ & - & B \\
\hline 12. & $\begin{array}{l}\text { Razvoj sistema za prikupljanje podataka o } \\
\text { otkazima }\end{array}$ & $\begin{array}{l}\text { Služba } \\
\text { obezbeđenja } \\
\text { kvaliteta }\end{array}$ & $\begin{array}{l}\text { Tehnička služba } \\
\text { kupca }\end{array}$ & A \\
\hline 13. & $\begin{array}{l}\text { Organizacija i izvođenje završnih ispitivanja i } \\
\text { prijema }\end{array}$ & $\begin{array}{l}\text { Opitni centar } \\
\text { (u daljem } \\
\text { tekstu: OC) }\end{array}$ & $\begin{array}{l}\text { Proizvođač i } \\
\text { tehnička služba } \\
\text { kupca }\end{array}$ & A \\
\hline 14. & $\begin{array}{l}\text { Prijem a eventualno i usvajanje } " 0^{\prime *} \text { serije (ako } \\
\text { to nije učinjeno već pri prijemu PT) }\end{array}$ & $\begin{array}{l}\text { Nadležni nivo } \\
\text { odlučivanja }\end{array}$ & - & A \\
\hline
\end{tabular}

(10) - Stručnjaci zaduženi za razrađu tehnoloških uslova proizvodnje

Tabela 12

Aktivnosti koje se realizuju u toku serijske proizvodnje

\begin{tabular}{|c|c|c|c|c|}
\hline $\begin{array}{c}\text { Redni } \\
\text { broj }\end{array}$ & \multicolumn{1}{|c|}{ Nazivaktivnosti } & \multicolumn{1}{|c|}{$\begin{array}{c}\text { Nosilac } \\
\text { realizacije }\end{array}$} & Sarađuje & $\begin{array}{c}\text { Obaveznost } \\
\text { primene }\end{array}$ \\
\hline 1 & \multicolumn{1}{|c|}{2} & 3 & 4 & 5 \\
\hline 1. & $\begin{array}{l}\text { Aktivnosti proizvodne službe obezbeđenja } \\
\text { kvaliteta }\end{array}$ & $\begin{array}{l}\text { Služba } \\
\text { obezbeđenja } \\
\text { kvaliteta }\end{array}$ & - & $\mathrm{A}$ \\
\hline 2. & $\begin{array}{l}\text { Proizvodnja specijalne remontne opreme, } \\
\text { grupnih kompleta r/d, alata i pribora i nastav- } \\
\text { nih sredstava }\end{array}$ & $\begin{array}{l}\text { Proizvodna } \\
\text { odeljenja }\end{array}$ & $\begin{array}{l}\text { Stručnjaci za } \\
\text { izradu uputstava }\end{array}$ & $\mathrm{A}$ \\
\hline
\end{tabular}




\begin{tabular}{|c|c|c|c|c|}
\hline 1 & 2 & 3 & 4 & 5 \\
\hline 3. & $\begin{array}{l}\text { Izrada konačne verzije Uputstva za tehničko } \\
\text { održavanje, Uputstva za srednji remont, kao } \\
\text { i Imenika s/d }\end{array}$ & $\begin{array}{l}\text { Stručnjaci } \\
\text { zaduženi za } \\
\text { izradu ove } \\
\text { dokumentacije }\end{array}$ & - & $\overline{\mathrm{A}}$ \\
\hline 4. & $\begin{array}{l}\text { Obuka kadra za tehnickko održavanje i srednji } \\
\text { remont }\end{array}$ & $\begin{array}{l}\text { Stručnjaci } \\
\text { zaduženi za } \\
\text { obuku }\end{array}$ & $\begin{array}{l}\text { Stručnjaci } \\
\text { drugih } \\
\text { isporučilaca }\end{array}$ & $\mathbf{A}$ \\
\hline 5. & Održavanje u toku garantnog roka & $\begin{array}{l}\text { Servisna } \\
\text { služba } \\
\text { proizvodača }\end{array}$ & $\begin{array}{l}\text { Tehnickka služba } \\
\text { kupca }\end{array}$ & A \\
\hline 6. & Obezbeđenje r/d & $\begin{array}{l}\text { Komercijala } \\
\text { kupca }\end{array}$ & $\begin{array}{l}\text { Prodajna } \\
\text { služba } \\
\text { proizvođaca }\end{array}$ & B \\
\hline 7. & $\begin{array}{l}\text { Pracenje ponasanja sredstava u toku početne } \\
\text { eksploatacije }\end{array}$ & $\begin{array}{l}\text { Služba za } \\
\text { marketing } \\
\text { proizvođađa }\end{array}$ & $\begin{array}{l}\text { Nosilac } \\
\text { razvoja }\end{array}$ & B \\
\hline 8. & $\begin{array}{l}\text { Rekonstrukcija sklopova, pribora i delova } \\
\text { softvera koji nisu zadovoljili zahteve u pogledu } \\
\text { eksploatacije, pouzdanosti i (ili) pogodnosti } \\
\text { za održavanje }\end{array}$ & $\begin{array}{l}\text { Razvojna } \\
\text { služba } \\
\text { proizvođaca }\end{array}$ & $\begin{array}{l}\text { Nosilac razvoja } \\
\text { kupca }\end{array}$ & B \\
\hline 9. & $\begin{array}{l}\text { Izrada nacrta tehnicke, remontne dokumenta- } \\
\text { cije za generalni remont tehničkog sistema ili } \\
\text { sredstva (ili davanje podataka za izradu ove } \\
\text { TRD) }\end{array}$ & $\begin{array}{l}\text { Razvojna } \\
\text { služba } \\
\text { proizvođača }\end{array}$ & - & B \\
\hline 10. & Prijem serijske proizvodnje & $\begin{array}{l}\text { Služba obez- } \\
\text { beđenja kvali- } \\
\text { teta proizvo- } \\
\text { đača i kupca }\end{array}$ & $\begin{array}{l}\text { Marketing } \\
\text { prodavca }\end{array}$ & A \\
\hline
\end{tabular}

Tabela 13

Aktivnosti koje se realizuju radi obezbeđenja ugradnje tehnickog sredstva u složeno sredstvo ili sistem, odnosno ugradnje tehnickog sistema u objekat

\begin{tabular}{|c|c|c|c|c|}
\hline $\begin{array}{c}\text { Redni } \\
\text { broj }\end{array}$ & Naziv aktivnosti & $\begin{array}{c}\text { Nosilac } \\
\text { realizacije }\end{array}$ & Sarađuje & $\begin{array}{l}\text { Obaveznost } \\
\text { primene }\end{array}$ \\
\hline 1 & 2 & 3 & 4 & 5 \\
\hline 1. & $\begin{array}{l}\text { Upoznavanje sa karakteristikama složenog } \\
\text { tehnickog sredstva (ili objekta) u koje treba } \\
\text { ugraditi razmatrano tehnickko sredstvo (ili si- } \\
\text { stem), kao i klima-mehaničkim uslovima koji } \\
\text { postoje u tom složenom sredstvu (ili objektu) }\end{array}$ & $\begin{array}{l}\text { Projektna or- } \\
\text { ganizacija koja } \\
\text { rešava prob-- } \\
\text { lem ugradnje }\end{array}$ & - & A \\
\hline 2. & $\begin{array}{l}\text { Projektovanje i izrada dopunskih uslova, pri- } \\
\text { bora i drugih elemenata koji omogucuju } \\
\text { ugradnju tehnickog sredstva u složeno sred- } \\
\text { stvo ili sistema u objekt }\end{array}$ & $\begin{array}{l}\text { Projektna or- } \\
\text { ganizacija koja } \\
\text { rešava prob- } \\
\text { lem ugradnje } \\
\end{array}$ & -2 & A \\
\hline 3. & $\begin{array}{l}\text { Projektovanje i realizacija izmena na slože- } \\
\text { nom sredstvu (ili objektu) koje omogucavaju } \\
\text { planiranu ugradnju tehniékog sredstva (ili si- } \\
\text { stema) }\end{array}$ & $\begin{array}{l}\text { Projektna or- } \\
\text { ganizacija koja } \\
\text { rešava prob- } \\
\text { lem ugradnje }\end{array}$ & $\begin{array}{l}\text { Specijalizovane } \\
\text { projektne izvo- } \\
\text { đacke organizacije }\end{array}$ & B \\
\hline 4. & $\begin{array}{l}\text { Provera nesmetanog rada i održavanje ugrade- } \\
\text { nog tehnickog sredstva (ili sistema) u eks- } \\
\text { tremno nepovoljnim uslovima rada složenog } \\
\text { sredstva (ifl objekta) }\end{array}$ & $\begin{array}{l}\text { Komisija } \\
\text { kupca I } \\
\text { prodavca }\end{array}$ & - & A \\
\hline 5. & $\begin{array}{l}\text { Provera da li je ugradnja tehničkog sredstva } \\
\text { uticala na pogoršanje uslova eksploatacije i } \\
\text { održavanja složenog sredstva ili sistema }\end{array}$ & $\begin{array}{l}\text { Komisija } \\
\text { kupca }\end{array}$ & - & A \\
\hline
\end{tabular}




\begin{tabular}{|c|c|c|c|c|}
\hline 1 & 2 & 3 & 4 & 5 \\
\hline 6. & $\begin{array}{l}\text { Eventualna izmena koncepta održavanja ugra- } \\
\text { đenog sredstva (ili sistema NVO) ili dotada- } \\
\text { Snjeg koncepta održavanja složenog sredstva } \\
\text { (ili objekta) }\end{array}$ & $\begin{array}{l}\text { Tehnicka } \\
\text { služba kupca }\end{array}$ & - & A \\
\hline 7. & $\begin{array}{l}\text { Utvrđivanje dopunskih potreba u pogledu } \\
\text { obezbeđenja odgovarajuce remontne podrśke } \\
\text { ugradenog tehnickog sredstva ili sistema }\end{array}$ & $\begin{array}{l}\text { Tehnicka } \\
\text { služba kupca }\end{array}$ & $\begin{array}{l}\text { Ustanova koja } \\
\text { reŠava problem } \\
\text { ugradnje }\end{array}$ & B \\
\hline 8. & $\begin{array}{l}\text { Donošenje rešenja o ugradnji tehničkog sred- } \\
\text { stva u složeno sredstvo ili o prijemu radova } \\
\text { na ugradnji tehnickog sistema u objekat }\end{array}$ & $\begin{array}{l}\text { Odgovarajuci } \\
\text { nivo odluci- } \\
\text { vanja kupca }\end{array}$ & - & A \\
\hline
\end{tabular}

Tabela 14

Aktivnosti koje se realizuju u toku eksploatacije i održavanja

\begin{tabular}{|c|c|c|c|c|}
\hline $\begin{array}{c}\text { Redni } \\
\text { broj }\end{array}$ & Naziv aktivnosti & $\begin{array}{l}\text { Nosilac } \\
\text { realizacije }\end{array}$ & Sarađuje & $\begin{array}{l}\text { Obaveznost } \\
\text { primene }\end{array}$ \\
\hline 1 & 2 & 3 & 4 & 5 \\
\hline 1. & $\begin{array}{l}\text { Prikupljanje podataka o problemima i otka- } \\
\text { zima u eksploataciji i odrzavanju }\end{array}$ & $\begin{array}{l}\text { Tehnickka } \\
\text { služba kupca }\end{array}$ & $\begin{array}{l}\text { Služba razvoja } \\
\text { proizvođača }\end{array}$ & $\bar{A}$ \\
\hline 2. & $\begin{array}{l}\text { Analiza podataka o problemima i otkazima u } \\
\text { eksploataciji i održavanju i predlaganje modi- } \\
\text { fikacija }\end{array}$ & $\begin{array}{l}\text { Služba razvoja } \\
\text { proizvodađa }\end{array}$ & $\begin{array}{l}\text { Tehniðka služba } \\
\text { kupca }\end{array}$ & - \\
\hline 3. & $\begin{array}{l}\text { Usavrక̌avanje tehničkog sistema i sredstva radi } \\
\text { poboljłanja uslova eksploatacije i održavanja }\end{array}$ & $\begin{array}{l}\text { Nosilac razvo- } \\
\text { ja ili/i } \\
\text { proizvođax }\end{array}$ & - & $\mathrm{C}$ \\
\hline 4. & $\begin{array}{l}\text { Ispitivanje stabilnosti i upotrebljivosti tehnic- } \\
\text { kih sredstava cije karakteristike degradiraju u } \\
\text { toku vremena }\end{array}$ & $\begin{array}{l}\text { Tehnicka } \\
\text { služba kupca }\end{array}$ & $\begin{array}{l}\text { Služba razvoja } \\
\text { proizvođača }\end{array}$ & A \\
\hline 5. & $\begin{array}{l}\text { Održavanje ili preuzimanje alata za proizvod- } \\
\text { nju s/d ili opreme za fabricko ispitivanje sklo- } \\
\text { pova }\end{array}$ & $\begin{array}{l}\text { Proizvodači } \\
\text { tehnickih } \\
\text { sredstava }\end{array}$ & $\begin{array}{l}\text { Kooperanti } \\
\text { proizvođača }\end{array}$ & B \\
\hline
\end{tabular}

Metodologiju treba primenjivati selektivno, zavisno od složenosti i namene tehničkog sistema ili sredstva, i tehničkoekonomske opravdanosti pojedinih aktivnosti i zadataka. Međutim, preporuka je da, ukoliko se, iz bilo kojih razloga, ustanovi da treba odstupiti od realizacije nekih od istaknutih aktivnosti ili zadata$\mathrm{ka}$, to se mora međusobno usaglasiti (kupac-prodavac-korisnik), i precizirati u okviru programa realizacije ugovora za razvoj $i$ proizvodnju, ili bar u izveštaju neke od propisanih (međunarodnim standardima) revizija projekata.
Literatura:

[1] MIL-STD-785; Reliability Program Plans for Systems and Equipment Development and Production

[2] MIL-STD-470; Maintainability Program Plans

[3] MIL-STD-472; Maintainability Predications

[4] MIL-STD-781; Reliability Test Plans

[5] MIL-STD-471; Maintainability Demonstration Test Plans

[6] Kodzopeljic, J.; Usavrłavanje koncepcije razvoja tehnickih sistema i sredstava - doprinos sistemu odrzavanja, XXI Majski skup odrzavalaca, Beograd, 1998.

[7] Kodzopeljic, J.; Pogodnost za rukovanje i odrzavanje motornih vozila - parametri i njihov sadrzaj, XXII Majski skup održavalaca, Banja Vrujci, 1999.

[8] SNO 8196: Aktivnosti i zadaci ITOB-a u toku veka sredstva ili sistema NVO (predlog) 